Folia Geobot (2011) 46: 117-136.

DOI 10.1007/s12224-010-9073-6

\title{
Meristem growth, phenology, and architecture in chamaephytes of the Iberian Peninsula: insights into a largely neglected life form.
}

\author{
Gabriel Montserrat-Martí1 ${ }^{1}$, Sara Palacioํㅜ, Rubén Milla ${ }^{2}$ and Luis Giménez-Benavides ${ }^{2}$. \\ ${ }^{1}$ Instituto Pirenaico de Ecología (CSIC), Apdo. 13034, 50080 Zaragoza, Spain \\ 2 Área de Biodiversidad y Conservación, Universidad Rey Juan Carlos, c/ Tulipán s/n, 28933 Móstoles, Madrid, \\ Spain
}

Authors for correspondence: Gabriel Montserrat-Martí (gmmarti@ipe.csic.es) and Sara Palacio (s.palacio@ipe.csic.es).

\begin{abstract}
Protection of resting buds and timing of shoot development are crucial morphological traits of plants growing in a seasonal climate. For eight species of Iberian chamaephytes with contrasting morphology and ecology, we explored the different growth stages within the morphogenetic cycle of the shoot (including the initiation, morphogenesis and maturation of vegetative and reproductive structures), the seasonality of these growth stages and their relationship with the general climate of the species distribution area. We evaluated the implications of morphogenetic cycles on the phenology, architecture and distribution of each species, and tried to identify good descriptors of these cycles for their inclusion in data bases of functional plant traits.

The morphology, activity and growth of meristems and the expansion of shoots were assessed periodically by dissecting buds under stereomicroscope. Plant phenology was recorded monthly for a minimum of 13 months on 15 marked plants of six out of the eight study species.

All species showed naked buds, with meristems protected by leaf primordia and surrounding young leaves. We identified five stages of growth that summarize the processes of organogenesis and expansion of primordia in study species. Depending on the temporal arrangement of these stages and the type of structures subtending renewal meristems, we identified two types of morphogenetic cycles in study species: naked buds formed on brachyblasts (short branches) that extend for a relatively long time by neoformation; and naked buds on little shoot primordia that remain concealed by part of subtending leaves and extend rapidly in spring (preformed growth) sometimes followed by a period of slow expansion by neoformation.

These morphogenetic cycles seem to be related to the general climate where study species grow: species with brachyblasts grow preferentially in areas with dry summers and not very cold winters, while species with shoot primordia protected by leaf structures tend to grow in areas with cold winters and not very dry summers. Some traits like the type and size of buds, or the type of morphogenetic cycle are quite easy to measure and provide important ecological information. These traits are good candidates to be included in plant trait data bases.
\end{abstract}

Key words: buds, plant trait data bases, expansion, morphogenetic cycle, organogenesis, pheno-morphology, primordia 


\section{Introduction}

Perennial plants undergo different cycles of growth and reproduction throughout their life time. Among these, the morphogenetic cycle of shoots includes the initiation, morphogenesis and maturation of vegetative and reproductive structures (Lems 1962). This cycle begins with the initiation of buds and ends with the dispersion of fruits produced by the shoots developed by these buds. Therefore, it encompasses the shoot-growth cycle defined by Nitta and Ohsawa (1998) as the orderly production of scales, cataphylls, foliage leaves and hypsophylls along the shoot axis, together with the formation and maturation of reproductive structures. The morphogenetic cycle makes part of a more general cycle that has received the name of phenomorphological cycle, which includes not only the initiation and morphogenesis of vegetative and reproductive structures, but also their death and shedding (Orshan 1989, Montserrat-Martí et al. 2004).

The morphogenetic cycle seems to be closely related to the phenology and climate adaptations of plant species (Lems 1962, Hoffmann \& Hoffmann 1976, Damascos et al. 2005) and to the allocation of meristems to different fates, with implications on plant architecture (Milla et al. 2008). The patterns of meristem allocation determine plant form and function, which may subsequently be shaped by the environment (Bonser \& Aarssen 2003). Consequently, the analysis of morphogenetic cycles can provide useful information for comparative studies that could be easily incorporated into plant trait data bases such as CLOPLA (Klimes \& Klimesová 1999), with a huge potential in ecological studies.

Despite its relevance, morphogenetic cycles have only been studied in a few plant species (Aydelotte \& Diggle 1997), which include mostly trees (for example, Sabatier et al. 2003, Jordy 2004, Yuceer et al. 2003, Sreekantan et al. 2001), some shrubs (Hoffmann \& Hoffmann 1976, Damascos et al. 2005) alpine plants (Aydedotte \& Diggle 1997, Diggle 1997, Meloche \& Diggle 2001, Larl \& Wagner 2006) and just two species of chamaephytes (Milla et al. 2008).

Chamaephytes are plants that display their renewal structures at a maximum height of $25 \mathrm{~cm}$ above soil surface (Raunkiaer, 1934), or at a maximum height of $80 \mathrm{~cm}$ when considering Mediterranean species (Orshan, 1982). They constitute an important and widespread life form in Mediterranean, arid and semi-arid environments, as they are better adapted to survive in dry environments than phanerophytes (Shmida \& Burgess, 1988). Many Mediterranean chamaephytes are seasonal heteromorphic evergreens (evergreen plants that change markedly the shape and volume of their transpiring body throughout the year). This type of plants is considered to be better adapted to Mediterranean climate than seasonal isomorphic plants (evergreen plants that do no change markedly these features throughout the year) (Orshan et al. 1989). Seasonal heteromorphic evergreens normally show two different types of branches: branches with short internodes or brachyblasts and branches with long internodes or dolichoblasts (Orshan et al. 1989). Apart from the differences in size, both types of branches usually have different types of leaves and different phenology of growth; brachyblasts bear small hard leaves and persist during the most restrictive periods of the year, whereas dolichoblasts bear comparatively larger and softer leaves, with a higher photosynthetic ability and cover the plant during the mildest periods of the year (Fig. 1) (Orshan 1989). Both types of branches give rise one to the other. Accordingly, brachyblasts develop in the axils of the leaves of dolichoblasts soon after their expansion and persist throughout the harshest periods of the year, expanding into a dolichoblasts in the next growth season (Orshan 1989). By the alternation of these different types of branches throughout the 
year, seasonal heteromorphic evergreens adjust their morphology, architecture and physiology to the seasonality of Mediterranean-type climates (Palacio et al. 2006). Brachyblasts can also serve as a bud bank for these species, enabling the regrowth of branches after disturbances such as fire or grazing, frequent in Mediterranean-type environments (Palacio et al. 2006, Christodoulakis et al. 1990).

In the Iberian Peninsula, chamaephytes grow in a great variety of environments and show a huge morphological and taxonomical diversity, including many endemisms and endangered species (Castroviejo et al. 1986-2010, Domínguez-Lozano 2000). Few studies have addressed the morphology and growth dynamics of buds and shoots of this group of plants (but see Orshan, 1972; Gray \& Schlesinger, 1981; Montserrat-Martí et al. 2004; Palacio $\&$ Montserrat-Martí, 2005). From these studies we know that Mediterranean chamaephytes tend to show naked buds, and that the seasonality of dolichoblast and brachyblast growth differs in chamaephytes adapted to different environmental conditions (Palacio \& MontserratMartí, 2005, 2006). However, little is known about the morphogenetic cycles of chamaephytes and the relationship between these cycles and the species architecture and the general climatic conditions where these species grow.

Table-1. Morphological and ecological characteristics of study species.

\begin{tabular}{|c|c|c|c|c|c|c|c|}
\hline Species & Growth form & Habitat & Climate & $\begin{array}{l}\text { Altitudina } \\
\text { I range } \\
\text { (m) }\end{array}$ & $\begin{array}{l}\text { Size } \\
(\mathrm{cm})\end{array}$ & $\begin{array}{c}\text { Presence } \\
\text { of } \\
\text { brachybla } \\
\text { sts }\end{array}$ & $\begin{array}{c}\text { Position } \\
\text { of } \\
\text { infloresce } \\
\text { nces }\end{array}$ \\
\hline $\begin{array}{l}L \quad i \quad n \quad u \quad m \\
\text { suffruticosum }\end{array}$ & $\begin{array}{c}\text { Woody, evergreen } \\
\text { seasonal } \\
\text { heteromorphic }\end{array}$ & Open scrublands & $\begin{array}{l}\text { Mediterranean } \\
\text { and Med. semi- } \\
\text { arid }\end{array}$ & $\begin{array}{l}80-850 \\
(1000)\end{array}$ & 80 & Yes & Terminal \\
\hline $\begin{array}{l}\text { Lepidi u m } \\
\text { subulatum }\end{array}$ & $\begin{array}{l}\text { Woody, summer } \\
\text { deciduous }\end{array}$ & $\begin{array}{l}\text { Open scrublands on } \\
\text { gypsum soils }\end{array}$ & $\begin{array}{l}\text { Mediterranean } \\
\text { semi-arid }\end{array}$ & $\begin{array}{l}150-1000 \\
(1200)\end{array}$ & 60 & Yes & Terminal \\
\hline 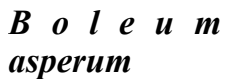 & $\begin{array}{c}\text { Woody, summer } \\
\text { deciduous }\end{array}$ & Open scrublands & $\begin{array}{l}\text { Mediterranean } \\
\text { semi-arid }\end{array}$ & $100-470$ & 60 & Yes & Terminal \\
\hline $\begin{array}{l}\text { Sat u } r e j a \\
\text { montana }\end{array}$ & $\begin{array}{c}\text { Woody, evergreen } \\
\text { seasonal } \\
\text { heteromorphic }\end{array}$ & $\begin{array}{l}\text { Gravels and open } \\
\text { scrublands }\end{array}$ & $\begin{array}{l}\text { Mediterranean } \\
\text { and sub- } \\
\text { Mediterranean }\end{array}$ & $\begin{array}{c}(200) \\
400-1800 \\
(2100)\end{array}$ & 50 & Yes & Terminal* \\
\hline $\begin{array}{l}O \quad n \quad o n \text { i s } \\
\text { fruticosa }\end{array}$ & $\begin{array}{l}\text { Woody, winter } \\
\text { deciduous }\end{array}$ & Open shrublands & $\begin{array}{c}\text { Sub- } \\
\text { Mediterranean }\end{array}$ & $320-1600$ & 100 & Yes & Terminal* \\
\hline $\begin{array}{l}\text { Echinospartu } \\
\text { m horridum }\end{array}$ & $\begin{array}{l}\text { Woody, thorny } \\
\text { cushion with green } \\
\text { stems and } \\
\text { deciduous leaves }\end{array}$ & $\begin{array}{l}\text { Crests, pastures and } \\
\text { open shrublands }\end{array}$ & $\begin{array}{c}\text { Sub- } \\
\text { Mediterranean } \\
\text { and mountain } \\
\text { climate }\end{array}$ & $\begin{array}{c}(400) \\
650-2100 \\
(2300)\end{array}$ & 80 & No & Terminal \\
\hline $\begin{array}{l}\text { Saxifraga } \\
\text { trifurcata }\end{array}$ & $\begin{array}{l}\text { Herbaceous, } \\
\text { pulvinular } \\
\text { evergreen }\end{array}$ & $\begin{array}{l}\text { Fissures in limestone } \\
\text { cliffs and rocks }\end{array}$ & Atlantic & $0-1500$ & 12 & No & Lateral \\
\hline $\begin{array}{l}\text { Saxifraga } \\
\text { canaliculata }\end{array}$ & $\begin{array}{c}\text { Herbaceous, } \\
\text { pulvinular } \\
\text { evergreen }\end{array}$ & $\begin{array}{l}\text { Fissures in limestone } \\
\text { cliffs and rocks }\end{array}$ & $\begin{array}{l}\text { Mountain } \\
\text { atlantic }\end{array}$ & $1000-2000$ & 10 & No & Terminal \\
\hline
\end{tabular}

Altitudinal ranges are shown for woody chamaephytes in Aragón (NE Spain) and Saxifraga species in the Cantabrian mountain range (N Spain). Plant distribution information obtained from Gómez García et al. (2005), Anthos project (www.anthos.es) and Vargas (1994). * Indicates that terminal inflorescences are made up of many small lateral inflorescences grouped in the distal end of reproductive shoots. 
The present study aims to highlight the relevance of considering the developmental cycle, fate and position of meristems when assessing the ecology and architecture of plants in relation to the seasonality of the climate where they live. We analysed the morphogenetic cycle of eight species of chamaephytes of the Iberian Peninsula as an example of the potential of this tool to understand the adaptation of plants to the environment. In particular, the objectives of this study were the following: 1) To identify general stages of growth in the morphogenetic cycles of study species and analyse their occurrence as related to seasonality; 2) To evaluate the implications of morphogenetic cycles on the phenology and architecture of study species; 3) To explore the general relationships between the features of the studied morphogenetic cycles, the structural and protective characteristics of buds and the general climate where chamaephytes are distributed in comparison with the better known phanerophytes. 4) To identify the variables that better summarize the morphogenetic information of plant species for their eventual inclusion into CLO-PLA or related data bases.

\section{Materials and methods}

\section{Species, study sites and climate}

The study was conducted in two separate areas of the Iberian Peninsula: North of Aragón (NE Spain) and Asturias (N Spain). Six out of eight species selected for study are representative of the most relevant growth forms of woody chamaephytes that grow naturally between the Ebro Basin and the Western Spanish Pre-Pyrenees: Echinospartum horridum (Vahl.) Rothm. (Fabaceae), Ononis fruticosa L. (Fabaceae), Satureja montana L. (Lamniaceae), Linum suffruticosum L. subsp. suffruticosum (Linaceae), Lepidium subulatum L. (Brassicaceae) and Boleum asperum (Pers.) Desv. (Brassicaceae). The remaining two species, Saxifraga trifurcata Schrad. (Saxifragaceae) and S. canaliculata Boiss. \& Reut. (Saxifragaceae), are herbaceous, pulvinular species endemic to the Atlantic area and the Cantabrian mountain range in the North of the Iberian Peninsula (Table 1).

Among the woody chamaephytes, E. horridum is representative of the thorny cushion plants (with persistent green stems) that grow at high altitudes in the Mediterranean mountains. Shoots of E. horridum are spiny, photosynthetic, and bear opposite stipulated deciduous leaves. $O$. fruticosa and $S$. montana grow at middle altitude within the study area. $O$. fruticosa is a winter deciduous species with alternate stipulate leaves, while $S$. montana is a seasonal heteromorphic species (Orshan 1989) that flowers and attains maximum green biomass in summer. Finally, L. suffruticosum, L. subulatum and B. asperum are representative of the seasonal heteromorphic species from semi-arid areas that flower and attain maximum photosynthetic biomass in early spring, similarly to most Mediterranean seasonal heteromorphic species (Mooney \& Kummerow, 1981, Palacio et al. 2006). L. subulatum and $B$. asperum lose most of the leaves in summer, while $L$. suffruticosum retains some of them during summer (Palacio et al. 2006). Figure 1 shows diagrams of the different types of branches of $B$. asperum in different phenological phases to illustrate the changes in the morphology of a seasonal heteromorphic species. Similar diagrams for the other study species can be found in Palacio \& Montserrat-Martí 2005, 2006 and Milla et al. 2008.

The studied Saxifraga species colonize fissures and small holes in limestone rocks. In our study area, $S$. trifurcata inhabits lowland rocky sites, ranging from 0 to $1500 \mathrm{~m}$ a.s.l. At ca. 1300-1400 $\mathrm{m} \mathrm{S}$. canaliculata replaces the lowland species, reaching $\sim 2000 \mathrm{~m}$. Both species behave as typical altitudinal vicariants (similar species that replace each other as altitude changes), with a very narrow contact zone at $\sim 1300-1400 \mathrm{~m}$. Both species are 
evergreen herbaceous plants with maintained growth during the vegetative season: a short spring growth flush (expansion of preformed elements) followed by a period of neoformation
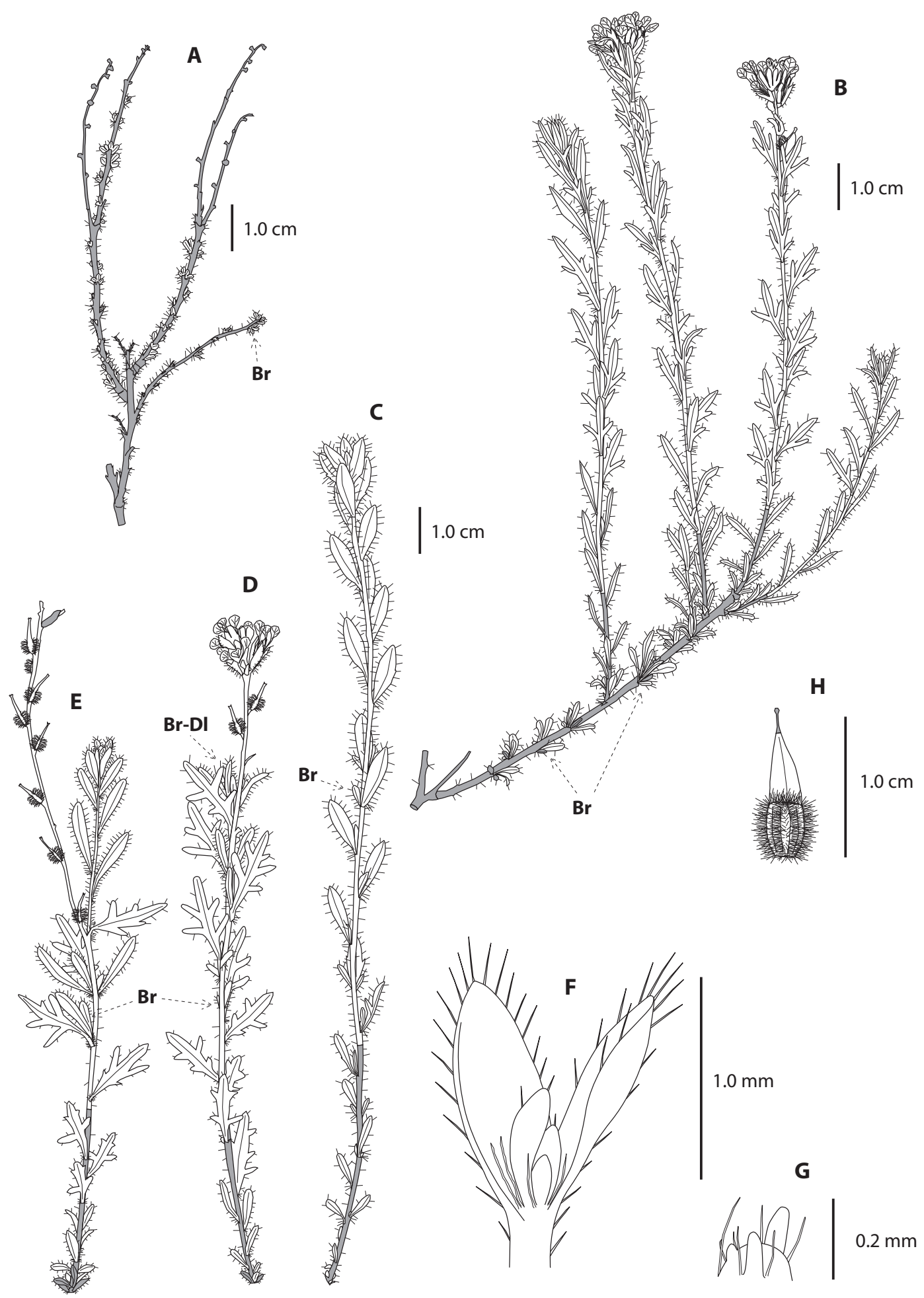

D
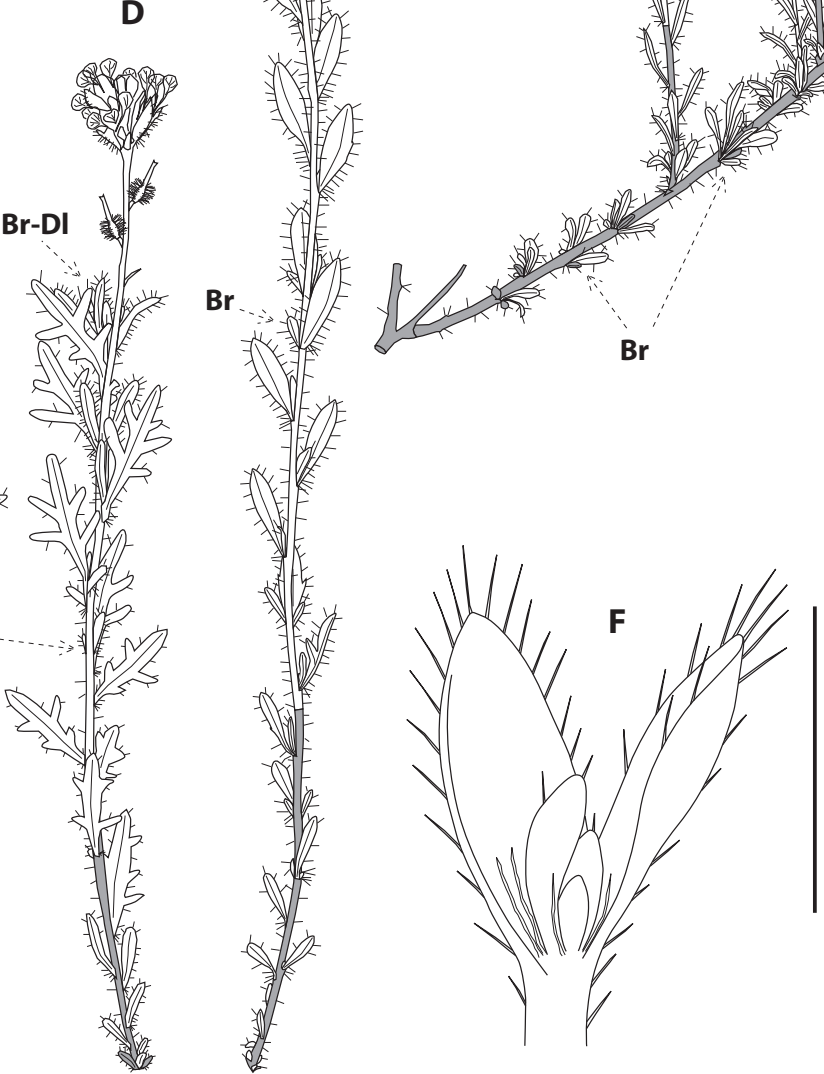

$1.0 \mathrm{~mm}$

G

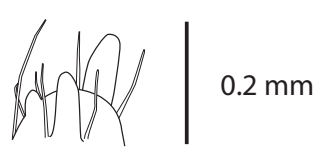

Figure 1. Diagram showing the morphology of the branches of Boleum asperum in different stages of the phenological cycle. A- Two-year-old branch on the $1^{\text {st }}$ October 2006, when the plant was only bearing small growing brachyblasts. B- Two-year-old branch on the $23^{\text {rd }}$ May 2004, just starting flowering and fruiting. C- Vegetative dolichoblast, $8^{\text {th }}$ May 2005. D- Dolichoblast in late flowering with immature fruits, $23^{\text {rd }}$ May 2004. E- Dolichoblast with immature fruits forming a lateral dolichoblast, $23^{\text {rd }}$ May 2004 . FDetail of the apical meristem showing the most distal leaf primordia, $12^{\text {th }}$ June 2005. G- Detail of the meristematic dome with three leaf primordia and their stipulae, $12^{\text {th }}$ June 2005 . H- Fruit completely

5 developed but still photosynthetic (unripe), $12^{\text {th }}$ June 2004. Elements in grey are dry, senescent or not photosynthetic, while green (photosynthetic) structures and petals are represented in white. Br: Brachyblast, Br-DI: Brachyblast actively developing into a dolichoblast. 
that extends throughout the season while environmental conditions are suitable (Milla et al. 2008). During the period of neoformed growth these species produce short internodes with leaves that are arranged in a rosette. Leaves are lobed, covered by resins and sticky.

All species but E. horridum and the Saxifraga species bear two types of branches: dolichoblast and brachyblasts (Table 1). In the present study, we consider short branches or brachyblasts as those branches shorter than $2 \mathrm{~cm}$, while long branches or dolichoblasts are branches longer than $2 \mathrm{~cm}$ (Fig. 1). All study species showed terminal inflorescences, except for Saxifraga trifurcata that had lateral ones (Table 1).

For each species of woody chamaephytes we selected a natural population composed of a minimum of 300 adult individuals. Studied populations were located with UTM coordinates (Universal Transverse Mercator coordinate system. Datum: ED50). E. horridum was studied in San Juan de la Peña Range, $25 \mathrm{~km}$ south-west of Jaca, Spain (UTM: 30T6894708; at $1380 \mathrm{~m}$ a. s. 1.), O. fruticosa was studied in a N-exposed limestone hillside near Bernués, Spain (UTM: 30T7014708; at 1020-1040 m), S. montana was studied in the riverside of the Guarga River, near Lasieso, Spain (UTM: 30T7104699; at $670 \mathrm{~m}$ ), L. suffruticosum and L. subulatum in a gypsum hill in the gypsum outcrops of Villamayor, near Zaragoza, Spain (UTM: 30T6884620; $320 \mathrm{~m}$ ), and B. asperum in the eroded miocene clays of Castelflorite, near Sariñena, Spain (UTM: 30T7454620; $360 \mathrm{~m}$ ). Climate in the highlands of Aragón is characterized by short summer drought periods and cold winters, with an increasing risk of winter frost as altitude increases. In the lowlands of Aragón the risk of winter frost is lower, but the length of summer drought increases remarkably. Climatic values range from $334 \mathrm{~mm}$ of average annual rainfall in the lowest areas to $1250 \mathrm{~mm}$ in the highest sites, and mean annual temperature ranges from $14.0^{\circ} \mathrm{C}$ in the lowest sites to $8.0^{\circ} \mathrm{C}$ in the highest ones.

Saxifraga species were sampled in an altitudinal gradient: four populations of $S$. trifurcata $(100,540,1064$ and $1360 \mathrm{~m}$ a.s.1.) and three of $S$. canaliculata $(1360,1430$ and $1872 \mathrm{~m}$ ), all localities included in the Asturias region: Porrúa (UTM: 30T3534807, $100 \mathrm{~m}$ ), Vis (UTM: 30T3284794, $540 \mathrm{~m}$ ), and several localities at "macizo occidental de los Picos de Europa": Lagos de Covadonga (UTM: 30T3374791, $1064 \mathrm{~m}$ ), Vegarredonda (UTM: 30T3384789, 1360-1430 m), and Cdo. La Fragua (UTM: 30T3394787, $1870 \mathrm{~m}$ ). Climate in the lowlands of Asturias region is of the oceanic humid type, with mild winters and warm summers, and turns colder and slightly more humid as altitude increases. The typical mediterranean summer drought is absent. The study area occupied by $S$. trifurcata shows an annual rainfall range of 1250 to $1630 \mathrm{~mm}$ and mean annual air temperatures of $6.9-14.7^{\circ} \mathrm{C}$, while that of $S$. canaliculata shows 1630 to $1680 \mathrm{~mm}$ annual rainfall and $3.9-6.9{ }^{\circ} \mathrm{C}$ mean annual air temperature.

Distribution maps of study species in the Iberian Peninsula are available at (http:// www.anthos.es/).

\section{Bud morphology and composition}

Sampling of woody species was conducted monthly between September 2002 and August 2007 during periods ranging from 13 to 39 months, whereas Saxifraga species were sampled between 2006 and 2007 in different periods: S. trifurcata was sampled in August 2006, November 2006 and March 2007, while S. canaliculata was sampled in August 2006, November 2006 and July 2007 (Table 1). These periods were found to capture accurately enough the different stages in the organogenetic activity of Saxifraga species (Milla et al. 2008). Differences in sampling date between species in 2007 were due to the longer period of 
winter rest of the species growing at higher locations, $S$. canaliculata.

At each sampling date, one branch between 3 and 5-year-old was collected in 10 random individuals per population. We obtained one or two shoots for analysis of each sample. Samples from woody chamaephytes were kept at $4{ }^{\circ} \mathrm{C}$ until dissection, which was performed in the following 48 hours, while samples from Saxifraga were kept frozen until dissection. In the latter species, resin was dissolved with acetone prior to bud analysis. To avoid variability due to bud position (Puntieri et al., 2002), shoots for analysis were always taken from the same position along the studied branch. Saxifraga species showed different types of branches that could differ in their organogenetic patterns. In order to obtain analogous shoot structures for comparison between the two species, we selected the branches that contributed most to the growth and reproduction of the plant. In $S$. trifurcata, the apical vegetative shoot of reproductive branches was the study unit. However, in $S$. canaliculata reproductive branches produce small, lateral and poorly-developed vegetative shoots that are less likely to reproduce the following year. Consequently, we selected the apical vegetative shoot of non-reproductive branches two or more years after branching as the study unit of this species (see Fig. 1 in Milla et al. 2008).

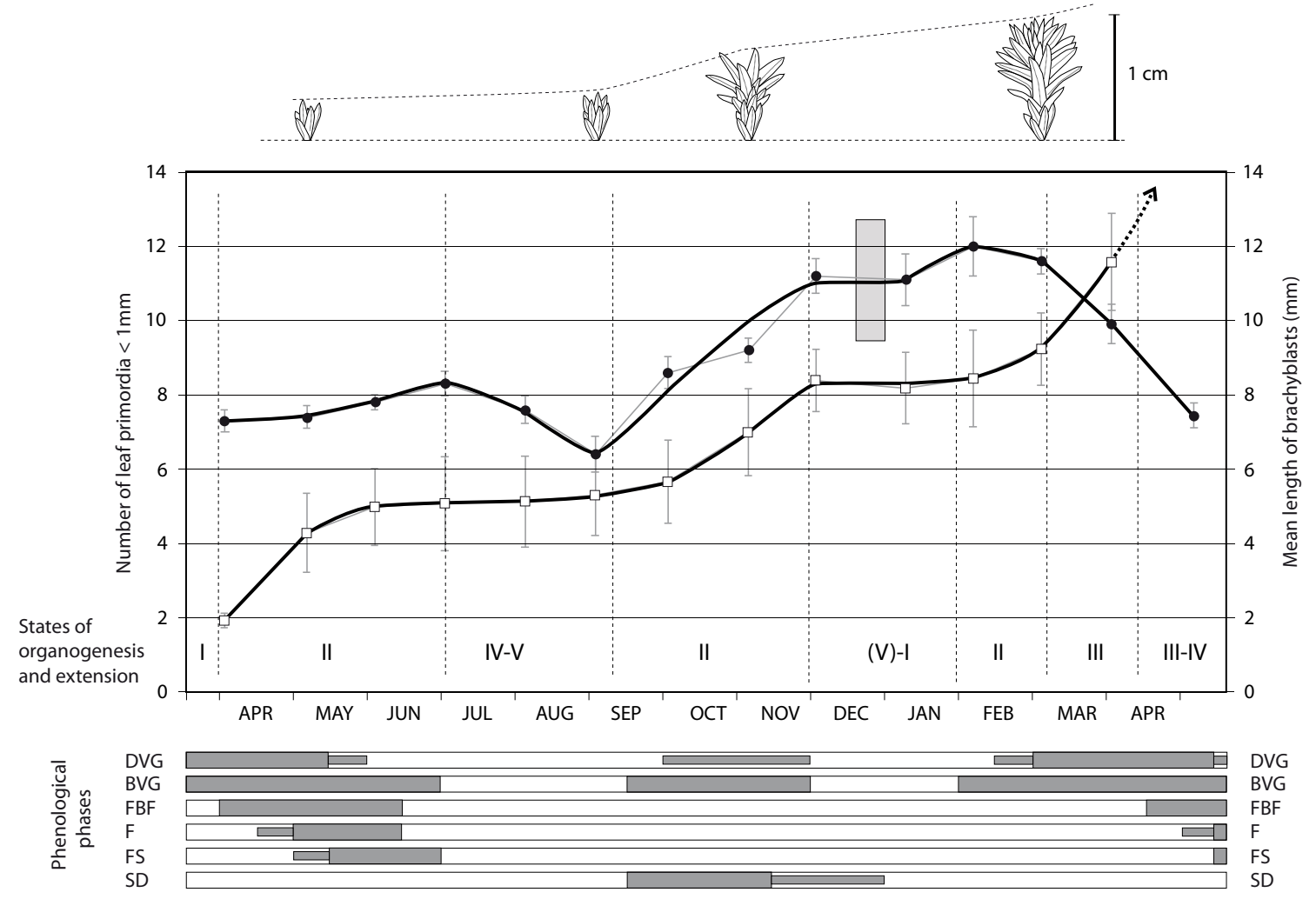

Figure 2. Representation of the morphogenetic cycle of Linum suffruticosum showing the different stages of organogenesis and expansion based on the integration of data recorded in the studied population between 2002 and 2004. The period shown includes the development of brachyblasts (short branches) and their expansion giving rise to dolichoblasts (long branches). Upper chart: illustration of an average brachyblast in each stage of the cycle: early May, September, November and March. Middle chart: average number of leaf primordia smaller than $1 \mathrm{~mm}$ in the apical bud of brachyblasts (-๑-), average length of branches (-ם-) and estimated timing of inflorescence initiation (grey rectangle). Data are means $\pm S E, n=10-20$. Lower chart: phenological phases in the study population of Linum suffruticosum. Fine grey lines: the phenophase occurs in 6-25\% individuals of the population. Thick grey lines: the phenophase occurs in more than $25 \%$ individuals of the population. DVG: dolichoblast vegetative growth (measurable to the naked eye), BVG: brachyblast vegetative growth (measurable to the naked eye), FBF: flower bud formation, F: flowering, FS: fruit setting, and SD: seed dispersal. 
Brachyblasts or shoot primordia were dissected acropetally (from the more proximal leaves to the apical meristem) under a stereomicroscope fitted with an ocular micrometer (MS5 and MZ125 Leica Microsystems, Heerbrugg, Switzerland). The total number of leaf primordia at each sampling date was counted and measured and their developmental stage was recorded. Structures considered as leaf primordia included all immature leaves longer than $0.025 \mathrm{~mm}$ (approximately the resolution limit of the stereomicroscope). The length of leaf primordia was measured from their insertion point on the immature stem to their distal end. The length and number of green and dry leaves of subtending shoots was also recorded, together with the presence of reproductive primordia, bract primordia and axillary meristems and the total length of the brachyblast.

\section{Phenology monitoring}

Aboveground phenology was studied monthly (only in woody chamaephytes) for a minimum of 13 months on 15 marked plants per species. In each marked individual we estimated the occurrence of the following phenophases: dolichoblast (i.e. long branch) vegetative growth (DVG), brachyblast (i.e. short branch) vegetative growth (BVG), flower bud formation (FBF), flowering (F), fruit setting (FS) and seed dispersal (SD). The percentage of each phenophase was estimated in the canopy of each individual and then compared with observations made on other unmarked individuals. This gave an integrated measure of the occurrence of each phenophase in the population. To graphically represent the intensity of each phenophase within the population, two categories were considered in the diagrams: 1 - when a phenophase was present in more than $25 \%$ of study plants, 2 - when it was present in between $>5$ and $25 \%$ of the individuals. Only phenophases occurring in more than $5 \%$ of the individuals were considered.

For more details on species, sites and methods see Milla et al. (2008) and Palacio and Montserrat-Martí (2005 and 2006).

\section{Results}

All species showed naked buds, i.e. meristems were not protected by special structures like hypsophylls, scales or cataphylls (Nitta and Ohsawa, 1998). Instead, apical meristems were protected by leaf primordia and the surrounding young leaves. The whole shoot primordia or the developing brachyblast (in the case of those species bearing two types of branches) was in turn protected by a leaf or part of it (stipulae, leaf bases, etc).

\section{Morphogenetic cycles and their relation to climate}

We identified five general stages of growth, common to all the chamaephytes studied, that summarize the different stages of organogenesis and expansion of primordia that take place throughout the morphogenetic cycle (Figs 2, 3 and 4):

I.- Initiation, development and accumulation of leaf primordia without any measurable expansion of branches.

II.- Initiation and development of leaf primordia with formation of small leaves and short internodes.

III.- Initiation and development of leaf primordia with formation of large leaves and long internodes.

IV.- Expansion of preformed structures without organogenesis.

V.- Inactivity of the meristem without organogenesis or measurable branch expansion. 


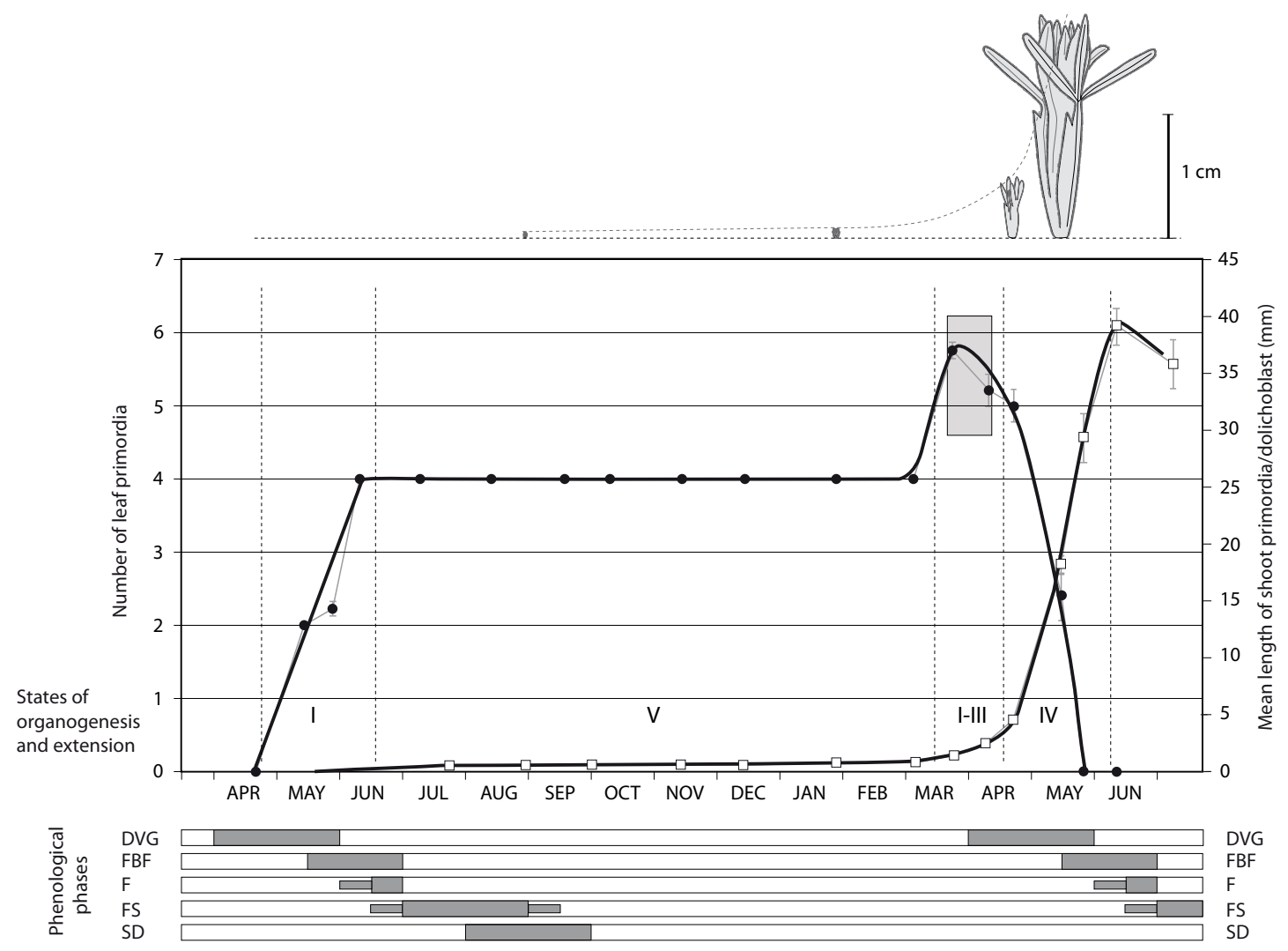

Figure 3. Representation of the morphogenetic cycle of Echinospartum horridum showing the different stages of organogenesis and expansion between 2002 and 2003. The period shown includes the development of shoot primordia and their expansion giving rise to a dolichoblast (long branch). Symbols and abbreviations as in Figure 2.

Depending on the temporal arrangement of these stages and on the type of structures subtending renewal meristems, we have identified two different types of morphogenetic cycles in study species: 1) early formation of a brachyblast (short branch) that grows for a relatively long time before expanding, in spring, into a dolichoblast (long branch) that will flower and fruit; and 2) early formation of a little shoot primordium that remains protected by part of the subtending leaf until it develops, in spring, into a vegetative or reproductive branch (Fig 4). In the first type, meristems form small adult leaves and very short internodes in their early stages of development giving rise to brachyblasts. Many species tend to produce progressively larger leaves in association with progressively longer internodes up to the beginning of dolichoblast development, when leaves extend much larger and internodes much longer. In the second type, meristems form shoot primordia, hence with no adult leaves or internodes, which remain concealed until the next spring, when all preformed primordia develop giving rise to a vegetative or a reproductive dolichoblast.

In the species showing the first type of morphogenetic cycle (L. suffruticosum, $L$. subulatum, B. asperum, S. montana and O. fruticosa), organogenesis and expansion of shoots take place for a long time, from about 4 months in $O$. fruticosa to 9.5 months in $L$. suffruticosum (Fig. 4). In the species that have no brachyblasts and show the second type of cycle (E. horridum, S. trifurcata and $S$. canaliculata), the period of shoot organogenesis and expansion can be either very short, as in E. horridum (less than 3 months), or rather long, as 
in Saxifraga species (more than 5 months) (Fig. 4). In Saxifraga such long period of growth is due to the protracted neoformed growth of the vegetative axis after the expansion of preformed primordia.

In the species with brachyblasts (first type of cycle), these are formed soon after the

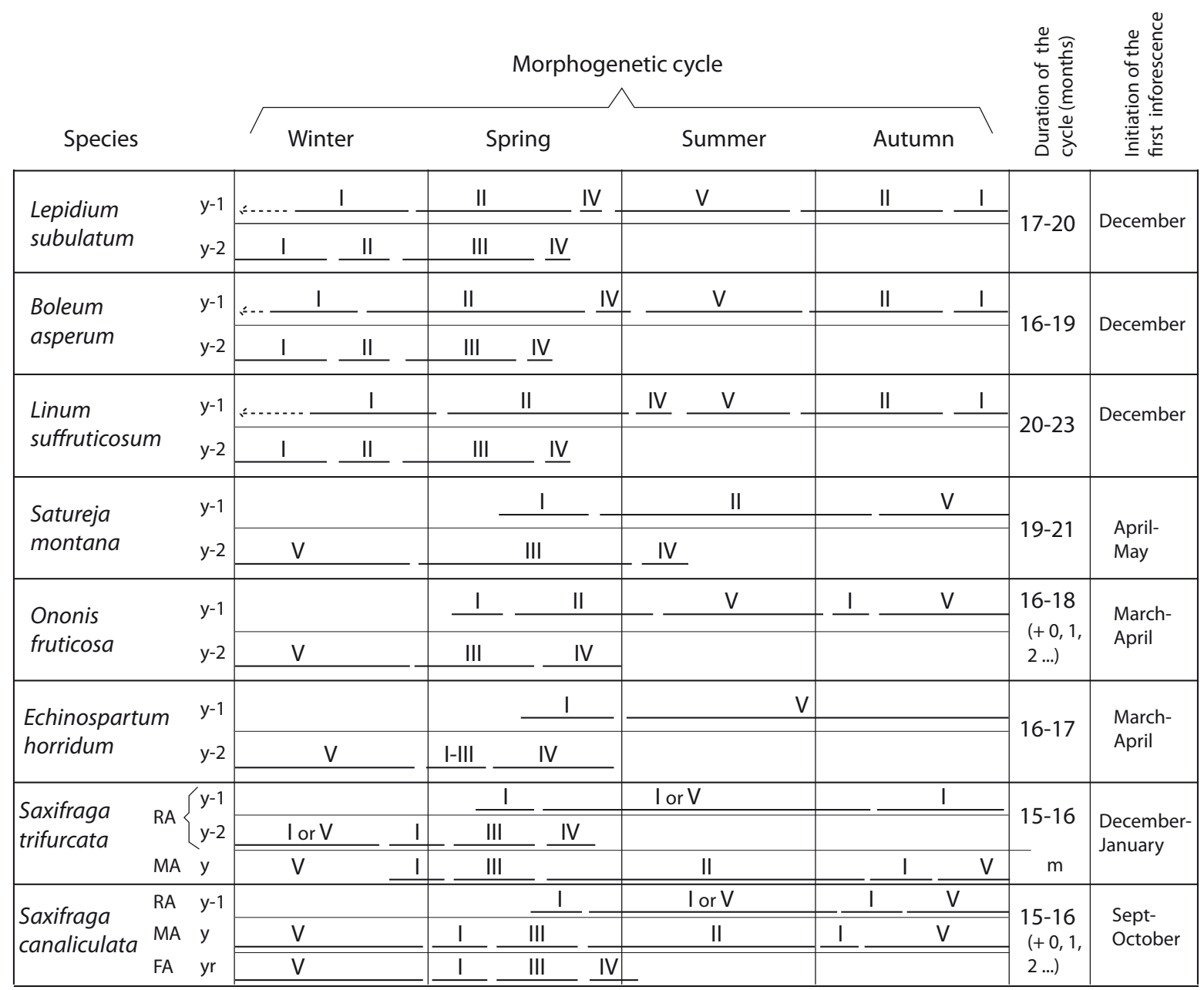

Figure 4. Morphogenetic cycles of all study species showing the different stages of organogenesis and expansion, the total duration of the morphogenetic cycle and the approximate timing of inflorescence initiation. Stages of growth through the morphogenetic cycle include: I: Initiation, development and accumulation of leaf primordia without any measurable expansion of branches; II: Initiation and development of leaf primordia with formation of small leaves and short internodes; III: Initiation and development of leaf primordia with formation of large leaves and long internodes; IV: Expansion of preformed structures without organogenesis; V: Inactivity of the meristem without organogenesis or measurable branch expansion. Numbers in parentheses indicate the duration of the cycle in years for some branch types. $\mathrm{RA}=$ ramification, $\mathrm{MA}=$ main axis, $\mathrm{FA}=$ reproductive axis, $\mathrm{y}-1=$ year $1, y-2=$ year $2, y=$ every year, $y r=$ year of reproduction, $m=$ monopodial growth, $(+0,1,2 \ldots)=$ the cycle can last one or more years.

beginning of the expansion of dolichoblasts. In L. suffruticosum, L. subulatum and B. asperum some brachyblasts may initiate in autumn, but most of them are formed in late winter. During winter, the organogenetic activity of meristems, i.e. the production of new leaf primordia, in brachyblasts is higher in species from low and dry areas (L. suffruticosum, L. subulatum and $B$. asperum) than in species growing at mid-altitude where conditions are colder (S. montana 
and $O$. fruticosa). In winter, species from cold spots arrest shoot expansion, but species from warm areas can maintain a certain production of leaf primordia and, in some cases, also a limited expansion of brachyblasts. Consequently, the species growing in dry and warm areas (B. asperum, L. subulatum and L. suffruticosum) show an accumulation of leaf primordia during winter (Figs. 2 and 4). These primordia expand quickly in spring, enabling a fast development of dolichoblasts. Meristem activity is completely arrested during cold winters or dry summers and in some cases the total length of brachyblasts can even decrease by drying and shedding their leaves. This happens in B. asperum and L. subulatum, which shed some or most of the leaves during summer drought, and in $O$. fruticosa, that sheds the leaves in autumn.

The species that do not have brachyblasts (second type of morphogenetic cycle) initiate very tiny shoot primordia soon after the expansion of subtending leaves. These shoot primordia, which include the primordia of most of the leaves of the future dolichoblasts $(E$. horridum) or part of them (Saxifraga spp.), grow only a few millimeters and remain concealed by the subtending leaf or part of it. Despite these species show a similar morphogenetic cycle, the different stages of organogenesis and expansion arrange differently in all of them. In E. horridum, organogenesis and shoot expansion take place only in spring. Shoot primordia extend in spring, developing dolichoblasts that flower, fruit and finish the morphogenetic cycle with the dispersion of fruits in summer. Contrastingly, in Saxifraga species, the production of leaf primordia is very slow, taking place even after the main axis stops growing. The main axis of the two species of Saxifraga can grow for several years, forming long internodes and large leaves in spring and short internodes and small leaves in summer and early autumn. During autumn and winter both species arrest shoot expansion, but some organogenesis can occur, leading to an accumulation of leaf primordia by the end of winter. These primordia will extend in spring. The lateral branches of both Saxifraga species are initiated in spring and remain as shoot primordia until the next spring, carrying out a slow production of leaf primordia when conditions are suitable and the main axis is not growing (Fig. 4).

Initiation of inflorescences and total duration of morphogenetic cycles

The inflorescences of species with brachyblasts were initiated (recorded as the first bract primordia noticeable) between two and four and a half months before flowering (Figs 2 and 4). Apparently, the time span between the initiation of inflorescences and the beginning of flowering is proportional to the amount of leaf primordia preformed within the bud that must extend before flowering. Accordingly, B. asperum, L. subulatum and L. suffruticosum show an average of 6-7, 8-9 and 12 leaf primordia smaller than $1 \mathrm{~mm}$ at the time of inflorescence initiation, and they flower 2-3, 3.5-4 and 4-4.5 months later, respectively (Figs. 2 and 4). In $S$. trifurcata inflorescence primordia are initiated at the apex of the largest axillary shoot primordium of relatively large leaf rosettes in December-January. In $S$. canaliculata inflorescences are initiated at the apex of main shoots of relatively large rosettes in September-October, after two or more years of vegetative development of the branch.

Morphogenetic cycles of study species last between 15 and 23 months (Fig. 4). However, the occurrence of different types of branches with different characteristics and longevities makes it difficult to assign a single value to some species. For example, $S$. canaliculata has branches that can remain vegetative for several years before flowering, and 
the monopodial axis of $S$. trifurcata persist until the apical bud dies (which can happen after several years) whereas its reproductive lateral branches follow a morphogenetic cycle of 15-16 months (Fig. 4). Also, in $O$. fruticosa some brachyblasts can persist for several years before dying or giving rise to a vegetative or reproductive dolichoblasts, whereas the most vigorous brachyblasts that give rise to reproductive dolichoblasts normally flower on the following year, completing the morphogenetic cycle in 16-18 months (Fig. 4).

\section{Discussion}

\section{Morphogenetic cycles and climate}

The two general types of morphogenetic cycles described here are closely related to the climatic conditions prevailing where study species grow. Our results suggest that the species with brachyblasts (short branches) tend to occupy areas where summer drought is severe but winter cold is only moderate. Contrastingly, the species with shoot primordia protected by leaf structures tend to grow in areas where winters are cold and summer drought is moderate or null.

One important characteristic common to species with brachyblasts (first type of cycle) and species with shoot primordia that grow for a long time (like both studied Saxifraga species), is the tendency to have few leaf primordia during summer and accumulate them in winter. These species grow at several periods of the year, taking advantage of the optimal and suboptimal periods so frequent in seasonal climates like the Mediterranean (Mitrakos 1980). By accumulating primordia in winter (preformed growth), they can perform a very fast shoot expansion in late winter or early spring, completing the morphogenetic cycle when environmental conditions are still suitable (Palacio \& Montserrat-Martí 2005). This response to seasonal climates, common to species with very different morphologies, may be possible because organogenesis seems to be more resistant to low temperatures than expansion. Also, immature leaf primordia seem to be more resistant to environmental stresses than expanding leaves or primordia in a more advanced development state. For example, younger leaf primordia of Manihot esculenta were found to be more resilient to drought periods than older primordia (Alves \& Setter 2004), and only the youngest flower primordia of Saxifraga bryoides could survive extremely cold temperatures (Ladinig \& Wagner 2009).

The species with shoot primordia protected by leaf structures (second type of cycle) tend to perform aboveground growth in a short time generally centred in spring. Such restriction of shoot growth seems to be an adaptation to cold mountain conditions or to environments where vegetative period is short. As an example, E. horridum performs all stages of shoot organogenesis and expansion in spring, showing a pattern similar to that of trees with preformed shoot growth that initiate a new cohort of primordia at the time of shoot expansion (Guédon et al. 2006, Sabatier et al. 2003). Concerning Saxifraga, the period of shoot growth is shorter in the highland species $(S$. canaliculata) than in the lowland species (S. trifurcata), since the highland species shows a later spring bud burst and an earlier initiation of inflorescences. The tendency to shorten the period of shoot growth in response to cold temperatures is also noticeable in some species bearing brachyblasts. For example, $O$. fruticosa, a species with brachyblasts growing in temperate sub-mediterranean areas, undertakes most of organogenesis and shoot expansion in spring (Table 2). 
Table 2. Summary of the relationship between growth stages and climate in study species.

\begin{tabular}{|l|c|c|l|}
\hline $\begin{array}{l}\text { Environ me ntal } \\
\text { conditions }\end{array}$ & Organogenesis & Expansion & \multicolumn{1}{|c|}{ Primary growth } \\
\hline Severe cold & $-/+$ & - & $\begin{array}{l}\text { Very reduced or no accumulation of } \\
\text { primordia. No appreciable branch } \\
\text { expansion. }\end{array}$ \\
\hline Severe drought & - & $\begin{array}{l}\text { Arrest of primordia formation. Buds } \\
\text { contain low numbers of primordia. } \\
\text { There is no expansion of branches } \\
\text { which can even decrease their size by } \\
\text { sedding some leaves. Only applicable } \\
\text { to the species from dry areas. }\end{array}$ \\
\hline $\begin{array}{l}\text { M o d e r a t e } \\
\text { climate stress }\end{array}$ & ++ & $+1++$ & $\begin{array}{l}\text { Production of leaf primordia with a } \\
\text { noticeable expansion of brachyblasts. } \\
\text { Production of short internodes and } \\
\text { small hard leaves. }\end{array}$ \\
\hline $\begin{array}{l}\text { Very low or no } \\
\text { climate stress }\end{array}$ & +++ & $+\begin{array}{l}\text { Active production of primordia and } \\
\text { intense development of dolichoblasts } \\
\text { with long internodes and large leaves. }\end{array}$ \\
\hline
\end{tabular}

Symbols: $-=$ no activity, $+=$ low,$++=$ moderate, and $+++=$ high .

Ecological implications of the duration of morphogenetic cycles

The total duration of the morphogenetic cycle is a key aspect to understand the temporal arrangement of phenological events and the adaptation of species to climate. Our observations indicate that several species of chamaephytes from the Iberian Peninsula perform morphogenetic cycles slightly longer than a year in which reproduction takes place at the end of vegetative growth. When plant investment in the morphogenetic cycle ends up with fruit production, this latter phenophase capitalizes exceeding resources at the end of the cycle (Suzuki 2000). This line of reasoning is important to understand the implications of having a longer or shorter morphogenetic cycle. We illustrate this by making use of the example of the ecological segregation of E. horridum and Erinacea anthyllis in the Pyrenees. E. anthyllis, a cushion plant morphologically and ecologically similar to E. horridum, shows a morphogenetic cycle 11-12 months longer than E. horridum. This species forms reproductive buds in spring in the upper nodes of dolichoblasts, but these buds do not open until the next spring (G. Montserrat-Martí, unpublished data). The need to expand the morphogenetic cycle is probably due to the reduced growth rate of E. anthyllis coupled to the short duration of the favorable period for shoot growth in the areas where it grows. Thanks to its longer morphogenetic cycle, E. anthyllis can complete vegetative growth and reproductive growth in a short optimal period in spring. This is achieved by completely overlapping vegetative and reproductive growth, with the subsequent drawback of increasing the competition for resources between these activities. Also, by splitting its morphogenetic cycle in two years, $E$. anthyllis has a low number of vegetative buds available each year (since half of the buds are reproductive). As a consequence, E. anthyllis shows a more open canopy than E. horridum. 
The above differences, coupled to the lower growth rate of E. anthyllis, result in the branches of $E$. horridum having each year more buds to start new morphogenetical cycles and more shoots that complete the cycle by flowering. Such greater potential for vegetative growth and seed production can explain the exclusion of E. anthyllis by the more competitive E. horridum from the areas of the Pyrenees where both species interact (Montserrat-Martí \& MontserratMartí 1984).

\section{Morphogenetic cycles and plant architecture and phenology}

Our results indicate that some differences in the morphogenetic cycle of species can lead to differences in their architecture. The most striking example is the different timing in the initiation of inflorescences of Saxifraga canaliculata and S. trifurcata, which could explain the differences in the position of inflorescences of both species. In these species, the initiation of flower primordia seems to be controlled by the photoperiod, as happens in Saxifraga oppositifolia and in many other alpine species (Keller \& Körner 2003, Larl \& Wagner 2006). However, the earlier initiation of inflorescences in $S$. canaliculata (a species with terminal inflorescences) takes place when the apical meristem of the main axis is still active and can hence form the inflorescence, while inflorescence initiation in S. trifurcata occurs about three months later, when the apical meristem of the main axis seems to be inactive and organogenesis only takes place in axillary meristems. This has important implications for their architectures, since $S$. canaliculata shows a denser and cushion-like shape, whereas the branching pattern of $S$. trifurcata is sparser. Milla et al. (2008) suggested that the different position of the inflorescences of both species could be related to the position of active meristems at the time of inflorescence initiation. However, these authors could not explain the different thresholds for organogenesis in meristems with different positions.
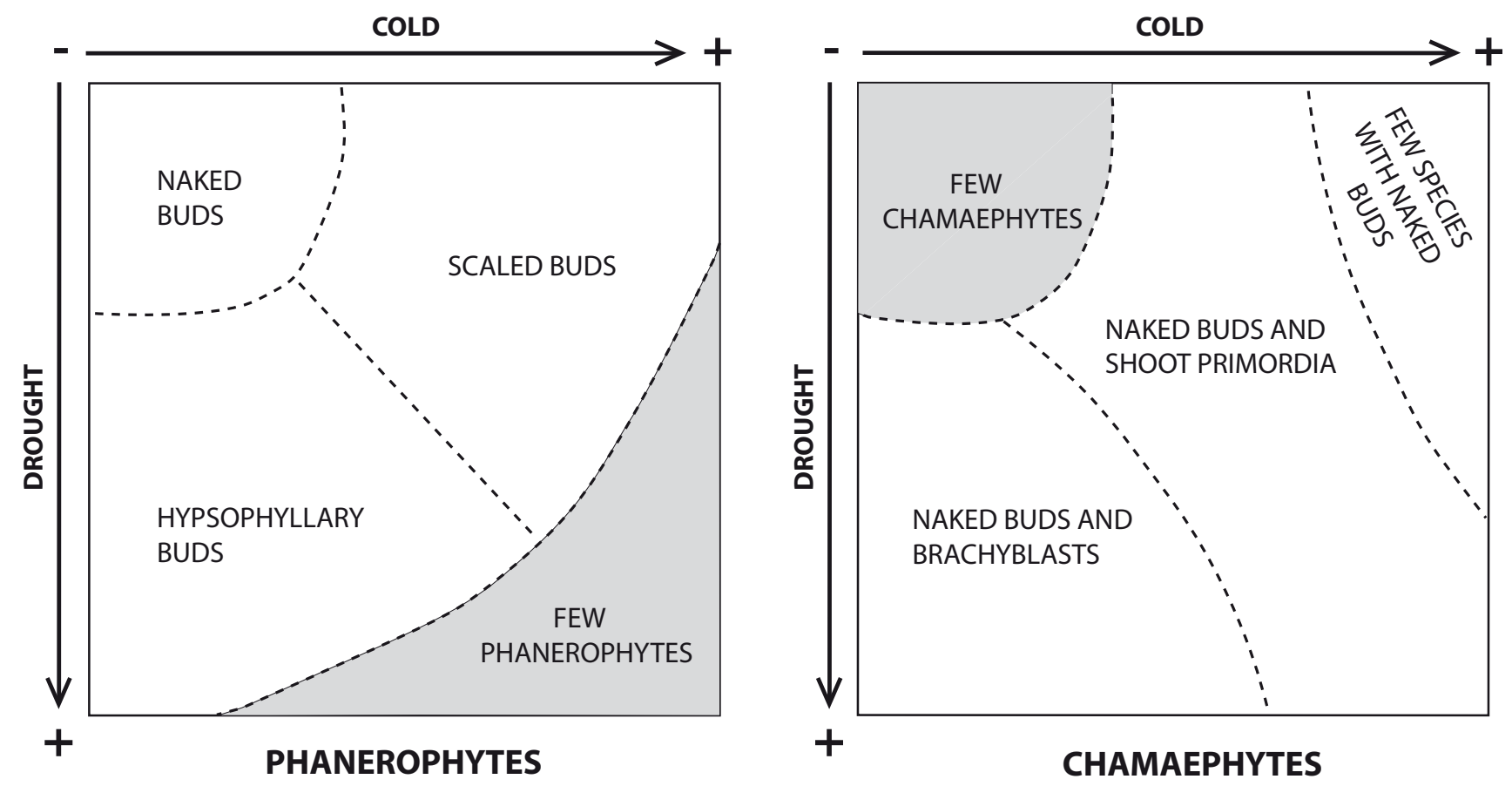

Figure 5. Diagram showing the preferential distribution, according to the proposed hypothesis, of phanerophytes with different types of buds (left) and chamaephytes with different types of buds and morphogenetic cycles (right) in relation to the intensity of cold and drought. See text for more details. 
In species with brachyblasts, the timing of inflorescence initiation does not seem to affect plant architecture. In these species, the number of leaf primordia preformed before the initiation of inflorescences seems to influence the starting time of reproductive phenology, as the development of such leaf primordia takes place before the expansion of reproductive primordia. Consequently, species showing more leaf primordia preformed within the bud at the time of inflorescence initiation will flower later than species with less preformed primordia.

\section{Bud morphology in relation to climate and growth form}

All study species showed naked buds, which suggests that this type of bud is predominant or very common among Iberian chamaephytes. Many species of alpine and subalpine chamaephytes also show naked buds (Yoshie 2008). The occurrence of the same type of bud in all study species seems to indicate that the observed differences in plant distribution, the arrangement of seasonal growth patterns and the duration of morphogenetic cycles are not related to the type of bud in these species of chamaephytes. However, naked buds are rare in phanerophytes from temperate and cold climates, which normally show buds protected by specialized structures such as hypsophylls, cataphylls and scales. Nitta \& Ohsawa (1998) described stratification in the dominance of naked, hypsophyllary and scaled buds in the species of the ground, understorey and canopy layers, respectively, of subtropical/warmtemperate rain forests. They suggested that the presence of hypsophylls, cataphylls and scales progressively increased bud protection against drought or cold stress, which explained current species distribution (Nitta \& Ohsawa 1998). Naked buds were the least protected type of bud and hence the most common among ground species (the least exposed ones). However, this interpretation does not explain the observed prevalence of naked buds within chamaephytes, since these species frequently grow in drier and colder areas than phanerophytes (Schmida \& Burgess 1988, Körner 1999).

To solve the paradox that chamaephytes, more stress-tolerant species than phanerophytes, have supposedly less protected buds, we suggest a new hypothesis, more general than the one by Nitta and Ohsawa (1998), that incorporates our observations on chamaephytes. Our hypothesis suggests that, when environmental stresses are low, the predictions of the hypothesis by Nitta and Ohsawa (1998) are valid and naked buds are the prevalent type of bud in species not only of chamaephytes, but also phanerophytes. When environmental stresses increase, the protective mechanisms of naked buds are no longer effective to protect the larger leaf primordia of phanerophytes, but work for smaller-sized woody plants. The size of leaves and stems is allometrically related to the size of the plant (Cornelissen 1999). Consequently, most chamaephytes bear small resistant leaves while leaves from phanerophytes tend to be larger and more delicate. If the allometric relationship holds for leaf primordia, this probably determines a higher stress resistance of the leaf primordia of smaller woody plants. Structures such as stipules or leaf bases can be quite robust and might provide enough insulation to meristems of small-sized species, such as, for example, the leaf bases of Echinospartum horridum, which are rigid and covered by a dense layer of hairs on their adaxial side (Palacio \& Montserrat-Martí 2006).

The two types of morphogenetic cycles described in this study enable us to identify two groups of chamaephytes with different distribution in relation to climate. These groups can be compared with the groups identified by Nitta and Ohsawa (1998) in phanerophytes with different bud types. Taking into account these results and the predictions of our 
hypothesis, we can suggest a preferential distribution of the different types of buds of woody species in relation to environmental stresses (drought and cold) as shown in Fig. 5. When droughts and cold are not extreme, species with naked buds might be prevalent. In areas where winter cold becomes the main environmental stress, phanerophytes with scaled buds might predominate, as scaled buds perform an important part of their development in summer (Nitta \& Ohsawa 1998, Montserrat-Martí et al. 2009). When summer drought is severe, phanerophytes with hyposphyllary buds might prevail. Hypsophyllary buds show low numbers of preformed leaf primordia during summer and produce most leaf primordia between autumn and early spring (Nitta \& Ohsawa 1998, Montserrat-Martí et al. 2004). Phanerophytes are normally absent from areas where both summer drought and winter cold are severe (Schmida \& Burgess 1988, Körner 1999) (Fig. 5).

According to our hypothesis, chamaephytes differ from phanerophytes in the distribution of the predominant types of buds in relation to environmental stresses (Fig. 5). Species of chamaephytes are normally rare in areas where environmental stress is low. Within chamaephytes, species with naked buds and brachyblasts may predominate in dry areas; while species with naked buds and shoot primordia protected by leaf structures may be prevalent in cold and dry areas. Finally, some species of chamaephytes from extremely cold areas show scaled instead of naked buds (Fig. 5). In the Pyrenees these are species like Prunus prostrata Labill. and Rhamnus pumila Turra (G. Montserrat-Martí, unpublished data).

\section{$\underline{\text { Final remarks }}$}

We highlighted the relevance of the study of the morphogenetic cycle of plants to gain a functional interpretation of phenological patterns and to understand the adaptation of plants to general climates. The remarkable lack of information on these matters, particularly in chamaephytes, has limited the depth of our analysis and the discussion of our results.

Despite the huge morphological and ecological diversity of Iberian chamaephytes (Castroviejo et al. 1986-2010), we found little variation in the morphogenetic cycles of these species. Such uniformity could be due to the lack of morphogenetic studies on these species, but also to the ability of these species to produce different phenological and architectural patterns from the same cycle.

Some of the traits included in our analysis, like the seasonal trends of organogenesis and the timing of inflorescence initiation, provide very relevant information, but are also hard to measure. Their incorporation in plant data bases such as CLO-PLA would require the identification of easy to measure, but so far unknown, estimators. However, other traits considered in this study, like the type and size of buds, the type of protective structures of buds and the protection they confer, or the general description of the morphogenetic cycle, are relatively easy to measure and provide important ecological information. It is, thus, surprising that even these simpler traits have only been studied in a few species. A strong effort should be made in the coming years to include such information in ecological data bases, if we aim to achieve a good knowledge of plant adaptation to the environment.

\section{Acknowledgements}

J. Klimesová and two anonymous referees provided useful comments to earlier versions of this manuscript. This study was possible thanks to the collaboration within the GLOBIMED network (Ministerio de Educación y Ciencia, Spain) and the financial support of the MECCICyT projects CGL2006-09431/BOS, CGL2007-66066-C04/BOS and CGL2008-04847- 
C02-01, DGA project GA-LC-011/2008, and INIA projects RTA2005-00100-C02-00 and SUM2006-00025-00-00. SP and RM were founded by a JAE-Doc CSIC and a Juan de la Cierva contract, respectively.

\section{References}

Alves, A.A.C. and T.L. Setter 2004. Response of cassava leaf area expansion to water deficit: cell proliferation, cell expansion and delayed development. Annals of Botany. 94:605-613.

Aydelotte, A.R. and P.K. Diggle 1997. Analysis of developmental preformation in the alpine herb Caltha leptosepala (Ranunculaceae). American Journal of Botany. 84:1646-1657.

Bonser, S.P. and L.W. Aarssen 2003. Allometry and development in herbaceous plants: functional responses of meristem allocation to light and nutrient availability. American Journal of Botany. 2003:404-412.

Castroviejo, S. et al. (Eds.) 1986-2010. Flora Iberica. 15 vols. Real Jardín Botánico CSIC, Madrid.

Cornelissen, J.H.C. 1999. A triangular relationship between leaf size and seed size among woody species: allometry, ontogeny, ecology and taxonomy. Oecologia. 118:248-255.

Christodoulakis, N.S., H. Tsimbani and C. Fasseas 1990. Leaf structural peculiarities in Sarcopoterium spinosum, a seasonally dimorphic subshrub. Annals of Botany. 65:291-296.

Damascos, M.A., C.H.B.A. Prado and C.C. Ronquim 2005. Bud composition, branching pattern and leaf phenology in Cerrado woody species. Annals of Botany. 96:1075-1084.

Diggle, P.K. 1997. Extreme preformation in alpine Polygonum viviparum: an architectural and developmental analysis. American Journal of Botany. 84:154-169.

Domínguez-Lozano, F. (Ed.), 2000. Lista roja de la flora vascular española (Red list of Spanish vascular flora). Conservación Vegetal No. 6. Universidad Autónoma de Madrid, Madrid, España.

Gómez García, D., Mateo, G., Mercadal, N., Montserrat, P., Sesé, J. A. 2005 onwards. Bibliografía botánica de Aragón. En "Atlas de la flora de Aragón. IPE(CSIC)Gobierno de Aragón. On-line edition (http://www.ipe.csic.es/floragon).

Gray, J.T. and W.H. Schlesinger 1981. Biomass, production, and litterfall in the coastal sage scrub of southern California. American Journal of Botany. 68:24-33.

Guédon, Y., J.G. Puntieri, S. Sabatier and D. Barthélémy 2006. Relative extents of preformation and neoformation in tree shoots: Analysis by a deconvolution method. Annals of Botany. 98:835-844.

Hoffmann, A.J. and A.E. Hoffmann 1976. Growth pattern and seasonal behavior of buds of Colliguaya odorifera, a shrub from the Chilean mediterranean vegetation. Canadian Journal of Botany. 54:1767-1774.

Jordy, M.-N. 2004. Seasonal variation of organogenetic activity and reserves allocation in the shoot apex of Pinus pinaster Ait. Annals of Botany. 93:25-37.

Keller, F. and C. Körner 2003. The role of photoperiodism in alpine plant development. Arctic, Antartic, and Alpine Research. 35:361-368.

Klimes, L. and J. Klimesová 1999. CLO-PLA2 - a database of clonal plants in central Europe. Plant Ecology. 141:9-19.

Körner, C. 1999. Alpine plant life. Functional plant ecology of high mountain ecosystems. 
Springer, Berlin.

Ladinig, U. and J. Wagner 2009. Dynamics of flower development and vegetative shoot growth in the high mountain plant Saxifraga bryoides L. Flora. 204:63-73.

Larl, I. and J. Wagner 2006. Timing of reproductive and vegetative development in Saxifraga oppositifolia in an alpine and subnival climate. Plant Biology. 8:155-166.

Lems, K. 1962. Adaptive radiation in the Ericaceae. I. Shoot development in the Andromedeae. Ecology. 43:524-528.

Meloche, C. and P.K. Diggle 2001. Preformation, architectural complexity, and developmental flexibility in Acomastylis rossii (Rosaceae). American Journal of Botany. 88:980-991.

Milla, R., Giménez-Benavides, L. \& Montserrat-Martí, G. 2008. Replacement of species along altitude gradients: The role of branch architecture. Annals of Botany 102:953-966.

Mitrakos, K.A. 1980. A theory for Mediterranean plant life. Acta Oecologica. 1:245-252.

Mooney, H.A. and J. Kummerow 1981. Phenological development of plants in Mediterranean-climate regions. In Mediterranean-type shrublands Eds. F. Di Castri, D.W. Goodall and R.L. Specht. Elsevier, Amsterdam, pp. 303-307.

Montserrat Martí, G., S. Palacio Blasco y R. Milla Gutiérrez. 2004. Fenología y características funcionales de las plantas leñosas mediterráneas. En: Ecología del bosque mediterráneo en un mundo cambiante. Editado por F. Valladares. Madrid.

Montserrat-Martí, J.M. and G. Montserrat-Martí 1984. Limites chorologiques de quelques plantes pyrénéennes. Documents d'Ecologie Pyrénéenne. 3-4:323-329.

Montserrat-Martí, G., Camarero, J.J., Palacio, S., Pérez-Rontomé, C., Milla, R., Albuixech, J. and M. Maestro. 2009. Summer-drought constrains the phenology and growth of two co-existing Mediterranean oaks with contrasting leaf habit. Trees 23: 787-799.

Nitta, I. and M. Ohsawa 1998. Bud structure and shoot architecture of canopy and understorey evergreen broad-leaved trees at their northern limit in East Asia. Annals of Botany. 81:115-129.

Orshan, G. 1972. Morphological and physiological plasticity in relation to drought. Proceedings of the International Conference on Wildland Shrub Biology and Utilization, Utah State Univ., pp. 245-254.

Orshan, G. 1982. Monocharacter growth form types as a tool in an analytic-synthetic study of growth forms in Mediterranean type ecosysstems. A proposal for an inter-regional program. Ecologia Mediterranea. 8:159-171.

Orshan, G. (Ed.) 1989. Plant pheno-morphological studies in Mediterranean type ecosystems. Kluwer Acad. Pub., Dordrecht.

Orshan, G., C. Floret, E.1. Floc'h, A.1. Roux, G. Montenegro and F. Romane 1989. General Synthesis. In Plant pheno-morphological studies in Mediterranean type ecosystems Ed. G. Orshan. Kluwer Acad. Pub., Dordrecht, pp. 389-399.

Palacio, S., Millard, P. and G. Montserrat-Martí. 2006. Aboveground biomass allocation patterns within Mediterranean sub-shrubs: a quantitative analysis of seasonal dimorphism. Flora 201: 612-622.

Palacio, S. and G. Montserrat-Martí. 2005. Bud morphology and shoot growth dynamics in two species of Mediterranean sub-shrubs co-existing in gypsum outcrops. Annals of Botany 95: 949-958. 
Palacio, S. and G. Montserrat-Martí. 2006. Comparison of the bud morphology and shoot growth dynamics of four species of Mediterranean sub-shrubs growing along an altitude gradient. Botanical Journal of the Linnean Society 151: 527-539.

Puntieri, J., Barthélémy, D., Mazzini, C. and C. Brion. 2002. Periods of organogenesis in shoots of Nothofagus dombeyi (Mirb.) Oersted (Nothofagaceae). Annals of Botany 89: 115-124.

Raunkiaer, C. 1934. The life forms of plants and statistical plant geography. Reprint Edition 1977 by Arno Press Inc. Ed. Clarendon Press, Oxford.

Sabatier, S., D. Barthelemy and I. Ducousso 2003. Periods of organogenesis in mono- and bicyclic annual shoots of Juglans regia L. (Juglandaceae). Annals of Botany. 87:117-123.

Shmida, A. and L. Burgess 1988. Plant growth-form strategies and vegetation types in arid enviroments. In Plant form and vegetation structure Eds. M.J.A. Werger, P.J.M.v.d. Aart, H.J. During and J.T.A. Verhoeven. SPB Academic Pub., The Hague, pp. 211-241.

Sreekantan, L., M.J. Mckenzie, P.E. Jameson and J. Clemens 2001. Cycles of floral and vegetative development in Metrosideros excelsa (Myrtaceae). International Journal of Plant Sciences. 162:719-727.

Suzuki, A. 2000. Patterns of vegetative growth and reproduction in relation to branch orders: The plant as a spatially structured population. Trees. 14:329-333.

Vargas, P. 1994. Estudios biosistemáticos en el género Saxifraga: serie Ceratophyllae (s.1.). PhD Thesis, Universidad Complutense de Madrid, Spain.

Yoshie, F. 2008. Dormancy of alpine and subalpine perennial forbs. Ecological Research. 23:35-40.

Yuceer, C., S.B. Land, M.E. Kubiske and R.L. Harkess 2003. Shoot morphogenesis associated with flowering in Populus deltoides (Salicaceae). American Journal of Botany. 90:196-206. 